\title{
Direct Determination of the Primary Binding Site of Cisplatin on Cytochrome $c$ by Mass Spectrometry
}

\author{
Ting Zhao and Fred L. King \\ C. Eugene Bennett Department of Chemistry, West Virginia University, Morgantown, West Virginia, USA
}

\begin{abstract}
Protein-cisplatin interactions lie at the heart of both the effectiveness of cisplatin as a therapeutic agent and side effects associated with cisplatin treatment. Because a greater understanding of the protein-cisplatin interactions at the molecular level can inform the design of cisplatin-like agents for future use, mass spectrometric determination of the binding site of cisplatin on a model protein, cytochrome $c$, was undertaken in this paper. The monoadduct cytochrome $c-\mathrm{Pt}\left(\mathrm{NH}_{3}\right)_{2}\left(\mathrm{H}_{2} \mathrm{O}\right)$ is found to be the primary adduct produced by the cytochrome $c$-cisplatin interactions under native conditions. To locate the primary binding site of cisplatin, both free cytochrome $c$ and the cytochrome $c$ adducts underwent trypsin digestion, followed by Fourier transform mass spectrometry (FT-MS) to identify unique fragments in the adduct digest. Four such fragments were found in the adduct digest. Tandem mass spectrometry (MS/MS and $\mathrm{MS}^{3}$ indicates that two fragments are $\mathrm{Pt}\left(\mathrm{NH}_{3}\right)_{2}\left(\mathrm{H}_{2} \mathrm{O}\right)$ bound peptides (Gly56-Glu104 and Asn54-Glu104) with one water associated at the peptide bond Lys79 Met80, and the other two fragments are heme containing peptides (acety1-Gly1-Lys53 and acety1-Gly1-Lys55). The product-ion spectra of the four fragments reveal that Met65 is the primary binding site of cisplatin on cytochrome $c$. (J Am Soc Mass Spectrom 2009, 20, 1141-1147) (C) 2009 American Society for Mass Spectrometry
\end{abstract}

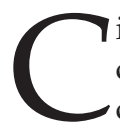
isplatin is effective in the treatment of various cancers, particularly testicular and ovarian cancers $[1,2]$. In the body, cisplatin interacts with DNA and thereby induces apoptosis in tumor cells [3, 4]. Because blood plasma proteins are good nucleophiles for cisplatin, they play an important role in transporting cisplatin to the tumor cells [5]. Unfortunately, some blood plasma protein-cisplatin binding is irreversible, which not only renders cisplatin inactive but also allows it to accumulate in tissues and induce side effects [6, 7]. Exploration of protein-platinum metallodrug interactions provides insight into both the transportation role of the blood plasma proteins that enables therapeutic use and the irreversible binding that induces side effects. This knowledge can be employed in the design of new therapeutic agents with increased effectiveness and reduced side effects.

Several analytical techniques have been applied to characterize cisplatin binding sites on model proteins. Nuclear magnetic resonance spectroscopy (NMR) was employed to locate the binding sites of cisplatin on human serum albumin [8] and cytochrome $c$ [9]. X-ray crystallography elucidated the crystal structures of superoxide dismutase-cisplatin adducts [10] and lysozymecisplatin adducts [11]. Electrospray ionization mass

Address reprint requests to Dr. F. L. King, C. Eugene Bennett Department of Chemistry, West Virginia University, P.O. Box 6045, Morgantown, WV 26506-6045, USA. E-mail: fred.king@mail.wvu.edu spectrometry (ESI-MS) $[12,13]$ coupled with the development of technologies for determining protein posttranslational modifications [14] enabled characterization of protein-Pt metallodrug interactions.

Gibson's group first reported the studies of the ubiquitin-cisplatin interactions using ESI-MS [15, 16]. Subsequently, the binding site of cisplatin on transferrin was determined by liquid chromatography tandem mass spectrometry (LC-MS/MS), providing the basis for molecular modeling of the transferrin-cisplatin interactions $[17,18]$. In addition, the performances of matrix-assisted laser desorption/ionization mass spectrometry (MALDI-MS) and ESI-MS were compared for the study of the ubiquitin-Pt metallodrug interactions [19]. More recently, Dyson and his coworkers [20] reported a rapid top-down approach to determine the binding sites of Pt metallodrugs on ubiquitin. Clearly, mass spectrometry has proven to be a powerful technique for the study of the protein-Pt metallodrug interactions.

Cytochrome $c$ is a small, well-characterized protein containing several potential binding sites for Pt metallodrugs including methionines and histidines [21]. Like ubiquitin, cytochrome $c$ is a common model protein that has been used to study the protein-Pt metallodrug interactions by ESI-MS and MS/MS. LC-MS/MS experiments, described in the literature [22], enabled the determination of the binding sites of carboplatin on cytochrome $c$. Although Casini et al. [23] reported the 
formation of the cytochrome $c$-cisplatin adducts using ESI-MS, they did not determine the binding site of cisplatin on cytochrome $c$. Recently, Casini et al. [24] reported a comprehensive study of the interactions of $\mathrm{Pt}$ (II) iminoethers with cytochrome $c$ including the determination of the primary binding site of $\mathrm{Pt}$ (II) iminoethers on cytochrome $c$ based on ESI-MS and NMR.

Assigning the location of a protein's binding site(s) for Pt metallodrugs is essential to better understanding the protein-Pt metallodrug interactions. This research describes direct determination of the binding site(s) of cisplatin on cytochrome $c$ via Fourier transform mass spectrometry (FT-MS) [25] and tandem mass spectrometry $\left(\mathrm{MS}^{n}\right)$. The high-resolution and high mass accuracy of FT-MS enable identification of different fragments in the adduct digest from those in the free cytochrome $c$ digest without need for a sample purification step. $\mathrm{MS}^{n}$ analyses of the unique fragments in the adduct digest provide their structural information and enable the determination of the binding site(s) of cisplatin based on the mass shift of $\mathrm{b}$ ions or $\mathrm{y}$ ions of the peptides in the Pt-compound containing fragments [26], revealed by broader isotope distributions of some product ions in their product-ion spectra [18].

\section{Experimental}

\section{Materials}

Horse heart cytochrome $c$, cisplatin, ammonium acetate $\left(\mathrm{NH}_{4} \mathrm{OAc}\right)$, and ammonium bicarbonate were purchased from Sigma (St. Louis, MO). Sequencing grade modified trypsin, methanol (HPLC grade), and acetic acid (HAc) (analytical grade) were obtained from Fisher Scientific (Pittsburgh, PA). All chemicals were purchased in highest purity available and used directly without further purification. Deionized water was used throughout the experiments.

\section{Preparation of the Cytochrome c-Cisplatin Adducts}

One hundred uM cytochrome $c$ was reacted with cisplatin at different molar ratios (cytochrome $c$ :cisplatin $1: 4,1: 8,1: 12$, and $1: 16$ ) under native conditions in $5 \mathrm{mM}$ $\mathrm{NH}_{4} \mathrm{OAc}$ aqueous solution $(\mathrm{pH} 6.8)$ at $37^{\circ} \mathrm{C}$ for different times to investigate the formation of the cytochrome $c-$ cisplatin adducts by ESI-MS. The cytochrome $c-$ cisplatin adducts used in protein digestion were prepared by reacting $100 \mathrm{uM}$ cytochrome $c$ with cisplatin at 1:16 cytochrome $c$ :cisplatin molar ratio at $\mathrm{pH} 6.8,37^{\circ} \mathrm{C}$ for $24 \mathrm{~h}$. Before ESI-MS, the cytochrome $c$ solutions were diluted to $100 \mathrm{nM}$ with a $30 \% \mathrm{MeOH}-5 \mathrm{mM}$ $\mathrm{NH}_{4} \mathrm{OAc}$ solution. Because the peak area of each species in the ESI-MS spectrum is linearly related to its concentration in solution at low concentrations [27], it is used to estimate the percentage of each cytochrome $c$ species in the solution by calculating the ratio of the peak area of the cytochrome $c$ species to the sum of the peak areas of all the cytochrome c species, under the assumption that there is no mass discrimination during the ESI-MS analyses of all the cytochrome $c$ species [28].

\section{Protein Digestion}

The cytochrome $c$-cisplatin adducts in the 1:16 cytochrome c:cisplatin mixture were diluted to $20 \mathrm{uM}$ with $50 \mathrm{mM} \mathrm{NH} \mathrm{NCO}_{3}(\mathrm{pH}$ 7.8) and then subjected to trypsin digestion at a protein to enzyme ratio of 50:1 (wt/wt) at $37^{\circ} \mathrm{C}$ for $70 \mathrm{~min}$. As a control, $20 \mathrm{uM}$ free cytochrome $\mathrm{c}$ was digested under the same conditions. Before ESI-MS analysis, the digest solution was diluted to $5 \mathrm{uM}$ with a $50 \% \mathrm{MeOH}-0.1 \%$ HAc buffer.

\section{ESI-MS Analyses of the Cytochrome c Adducts}

ESI-MS analyses of free cytochrome $c$ and the cytochrome $c$-cisplatin adducts were carried out on a quadrupole ion trap mass spectrometer coupled with a standard electrospray ionization source (Finnigan LCQ, San Jose, CA). The heated metal capillary was maintained at $200^{\circ} \mathrm{C}$. The spray voltage was set to $4.5 \mathrm{kV}$. Nitrogen was used as the sheath gas and its flow rate was 30 units $/ \mathrm{min}$. The capillary voltage and the tube lens voltage were held at 35 and $10 \mathrm{~V}$, respectively. The cytochrome $c$ solutions were introduced by direct infusion with a flow rate of $3 \mathrm{uL} / \mathrm{min}$. Ion optics were tuned at $1766 \mathrm{~m} / \mathrm{z}$. A mass range of $1500-2000 \mathrm{~m} / \mathrm{z}$ was used to collect ESI-MS spectra. The ESI-MS spectra were deconvoluted using MagTran software [29]. OriginPro 8 (OriginLab Corporation, Northampton, MA) was used to plot the data obtained in preparation of the cytochrome $c$ - cisplatin adducts.

\section{FT-MS, MS/MS, and $M S^{3}$ Analyses}

FT-MS, MS/MS, and MS ${ }^{3}$ analyses of the cytochrome $c$ digests were carried out on a Thermo Finnigan LTQ-FT system equipped with an Ion Max ion source (San Jose, CA). The operating conditions of the ESI source were mentioned above. The digests were introduced by direct infusion at $3 \mathrm{uL} / \mathrm{min}$. Ion optics were tuned for the ions of interest. FT-MS analyses of the free cytochrome $c$ digest and the adduct digest in a mass range of $500-2000 \mathrm{~m} / \mathrm{z}$ were performed to identify unique fragments in the adduct digest. Those fragments appearing uniquely in the FT-MS spectrum of the adduct digest were subjected to MS/MS and $\mathrm{MS}^{3}$ in the linear ion trap. The isolation width was set to $5 \mathrm{~m} / \mathrm{z}$. He was used as the collision gas. The amplitude of normalization collision energy (NCE) was $30 \%$ in MS/MS and $\mathrm{MS}^{3}$. Before collision induced dissociation (CID), the ions of interest were accumulated for 150 to $500 \mathrm{~ms}$ to increase ion intensity. The isotope distributions of product ions were obtained by zoom scan. All product spectra were recorded in a full mass range during the MS/MS and $\mathrm{MS}^{3}$ analyses of the digests. The product spectra were replotted and labeled in Origin 6.0 (OriginLab Corporation, Northampton, MA). ExPASy Proteomics Server 
was used to search the cytochrome $c$ sequence and to calculate the theoretical mass of the fragments in the adduct digest and the product ions of the peptides involved.

\section{Results and Discussion}

\section{Preparation of the Cytochrome c-Cisplatin Adducts}

The formation of the cytochrome $c$ adducts in three solutions, containing cytochrome $c$ and cisplatin at molar ratios of 1:4,1:8, and 1:12, respectively, was examined at different time intervals over $30 \mathrm{~h}$ to monitor the adduct formation. Throughout these studies, $12,604.3 \mathrm{Da}$ is the primary adduct ion observed in the deconvoluted ESI-MS spectra. This signal is assigned as monoadduct cytochrome $c$ - $\mathrm{Pt}\left(\mathrm{NH}_{3}\right)_{2}\left(\mathrm{H}_{2} \mathrm{O}\right)$ because the formation of the adduct results in a mass shift of 245.9 Da from free cytochrome $c$ (measured mass $12,358.4 \mathrm{Da})$, which is close to the theoretical mass of $\mathrm{Pt}\left(\mathrm{NH}_{3}\right)_{2}\left(\mathrm{H}_{2} \mathrm{O}\right)(246.026 \mathrm{Da})$. No cytochrome $c-\operatorname{Pt}\left(\mathrm{NH}_{3}\right)_{2} \mathrm{Cl}$ is detected, indicating that the side chains of cytochrome $c$ replace one water in hydrolyzed cisplatin $\mathrm{Pt}\left(\mathrm{NH}_{3}\right)_{2}\left(\mathrm{H}_{2} \mathrm{O}\right)_{2}$ yielding cytochrome $c-\mathrm{Pt}\left(\mathrm{NH}_{3}\right)_{2}\left(\mathrm{H}_{2} \mathrm{O}\right)$ [19]. For clarity, the charge states of the $\mathrm{Pt}$ compounds are omitted in this paper. The formation of cytochrome $c-\mathrm{Pt}\left(\mathrm{NH}_{3}\right)_{2}\left(\mathrm{H}_{2} \mathrm{O}\right)$ is described by eqs 1 and 2 :

$$
\begin{aligned}
& \mathrm{Pt}\left(\mathrm{NH}_{3}\right)_{2} \mathrm{Cl}_{2}+2 \mathrm{H}_{2} \mathrm{O} \rightleftarrows \mathrm{Pt}\left(\mathrm{NH}_{3}\right)_{2}\left(\mathrm{H}_{2} \mathrm{O}\right)_{2}+2 \mathrm{Cl} \\
& \mathrm{cytc}+\mathrm{Pt}\left(\mathrm{NH}_{3}\right)_{2}\left(\mathrm{H}_{2} \mathrm{O}\right)_{2} \rightleftarrows \mathrm{cytc}-\mathrm{Pt}\left(\mathrm{NH}_{3}\right)_{2}\left(\mathrm{H}_{2} \mathrm{O}\right)+\mathrm{H}_{2} \mathrm{O}
\end{aligned}
$$

Because the peak area of the monoadduct cytochrome $c-\mathrm{Pt}\left(\mathrm{NH}_{3}\right)_{2} \mathrm{H}_{2} \mathrm{O}$ covers over $90 \%$ of the sum of the peak areas of all the cytochrome $c$-cisplatin adducts in each spectrum, the percentage of cytochrome $c-\mathrm{Pt}\left(\mathrm{NH}_{3}\right)_{2} \mathrm{H}_{2} \mathrm{O}$ in the total cytochrome $c$ of each solution is used to represent the formed adducts. Figure 1 shows the changes of the percentage of cytochrome $c-\mathrm{Pt}\left(\mathrm{NH}_{3}\right)_{2} \mathrm{H}_{2} \mathrm{O}$ in three solutions over $30 \mathrm{~h}$. Although more cytochrome $c-\mathrm{Pt}\left(\mathrm{NH}_{3}\right)_{2} \mathrm{H}_{2} \mathrm{O}$ appears in the solution with a higher cisplatin concentration, the trends of the formation of cytochrome $c-\mathrm{Pt}\left(\mathrm{NH}_{3}\right)_{2} \mathrm{H}_{2} \mathrm{O}$ are similar in the three solutions. The percentage of cytochrome $c-\mathrm{Pt}\left(\mathrm{NH}_{3}\right)_{2}\left(\mathrm{H}_{2} \mathrm{O}\right)$ in all three solutions increases sharply during the first $5 \mathrm{~h}$, and then increases gradually until $21 \mathrm{~h}$, after which it remains constant indicating the attainment of equilibrium. In this research, $24 \mathrm{~h}$ is used as the reaction time to prepare the cytochrome $c$-cisplatin adducts for protein digestion.

Figure 2 shows the deconvoluted ESI-MS spectra, obtained using a quadrupole ion trap, of free cytochrome $c$ and the cytochrome $c$-cisplatin adducts prepared by reacting $100 \mathrm{uM}$ of cytochrome $c$ with cisplatin at different cytochrome $c$ :cisplatin molar ratios (1:8, $1: 12$, and 1:16) under native conditions for $24 \mathrm{~h}$. The mass accuracy for these ion trap data is $2 \mathrm{Da}$. Three

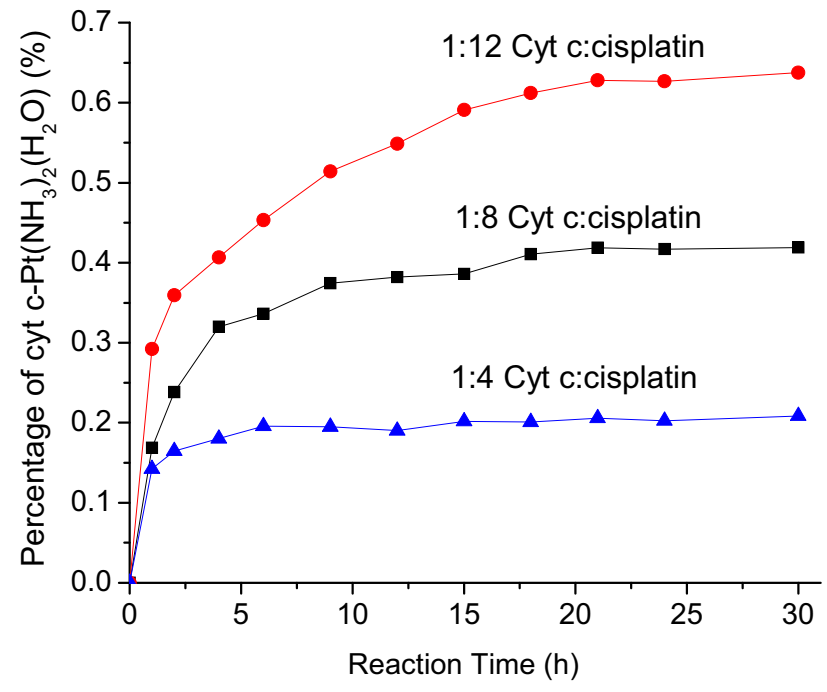

Figure 1. The percentage of cytochrome $c-\mathrm{Pt}\left(\mathrm{NH}_{3}\right)_{2}\left(\mathrm{H}_{2} \mathrm{O}\right)$ in three cytochrome $c$-cisplatin solutions: (filled triangle) 1:4 cytochrome c:cisplatin; (filled square) 1:8 cytochrome c:cisplatin; (filled circle) 1:12 cytochrome $c$ :cisplatin at different time intervals over $30 \mathrm{~h}$.

groups of peaks are observed, arising from free cytochrome $c$, the 1:1 cytochrome $c$ :cisplatin adducts (monoadducts), and the 1:2 cytochrome c:cisplatin adducts (diadducts), respectively. In all of these spectra, the diadduct signal is extremely low, indicating that monoadducts are the major adducts. Besides the primary monoadduct cytochrome $c-\mathrm{Pt}\left(\mathrm{NH}_{3}\right)_{2}\left(\mathrm{H}_{2} \mathrm{O}\right)$, the other monoadducts are assigned as cytochrome $c-\mathrm{Pt}\left(\mathrm{NH}_{3}\right)$, cytochrome $c-\mathrm{Pt}\left(\mathrm{NH}_{3}\right)_{2}$, cytochrome $c-\mathrm{Na}-\mathrm{Pt}\left(\mathrm{NH}_{3}\right)_{2}\left(\mathrm{H}_{2} \mathrm{O}\right)$, and cytochrome $c-\mathrm{H}_{2} \mathrm{O}-\mathrm{Na}-\mathrm{Pt}\left(\mathrm{NH}_{3}\right)_{2}\left(\mathrm{H}_{2} \mathrm{O}\right)$ corresponding to the small peaks at $12,569.0,12,586.2,12,626.7$, and $12,644.3 \mathrm{Da}$ [30]. Because these spectra also indicate that the largest amount of adducts are produced in the 1:16 cytochrome $c$-cisplatin solution, this solution is selected for the preparation of the cytochrome $c$-cisplatin adducts for trypsin digestion in the following studies conducted using an FT-MS system.

\section{Determination of the Primary Binding Site of Cisplatin on Cytochrome $c$}

Protein digestion. $\mathrm{MS}^{n}$ analyses of smaller fragments arising from trypsin digestion of the cytochrome $c$-cisplatin adducts provide information regarding the adduct structure. Because the stable cytochrome $c-$ cisplatin adducts were obtained under native conditions, trypsin digestion was performed under native conditions to prevent dissociation of the Pt-compounds from cytochrome $c$ and cytochrome $c$ fragments. A 50 $\mathrm{mM} \mathrm{NH} \mathrm{HCO}_{3}$ aqueous solution ( $\mathrm{pH} \mathrm{7.8)}$ held at $37^{\circ} \mathrm{C}$ was used for optimal conditions in trypsin digestion [31]. Initially, free cytochrome c was digested under the above conditions for $70 \mathrm{~min}$ to serve as the experimental control. FT-MS analysis of the free cytochrome c digest indicates complete digestion (spectrum not shown). Small peptides with low charge states from 1 to 


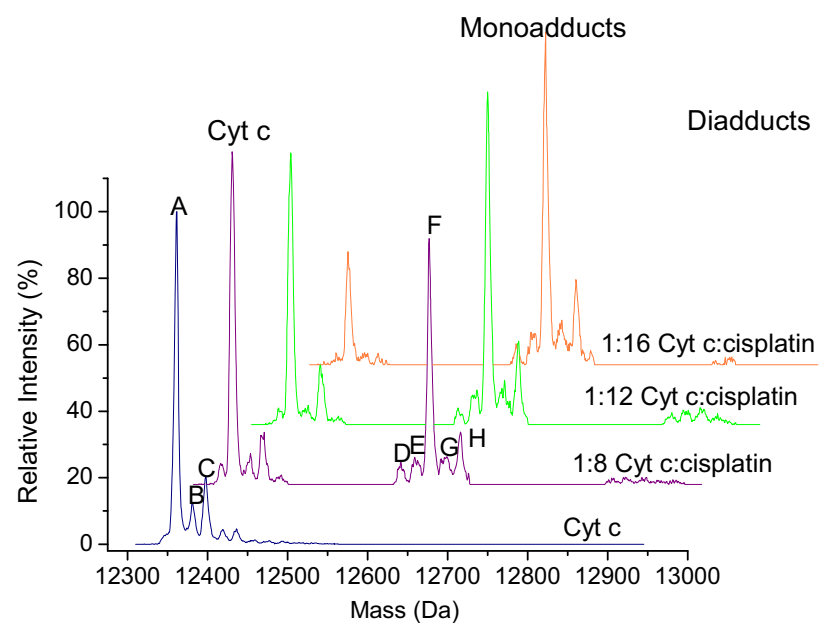

Figure 2. Deconvoluted ESI-MS spectra of free cyt $c$ and the cyt $c$-cisplatin adducts obtained by incubating cyt $c$ and cisplatin at different molar ratios for $24 \mathrm{~h}$ under native conditions. The assignment of individual peaks in the mass spectra: A - cyt $c(12,358.4$ Da); $\mathrm{B}$ - cyt $c-\mathrm{H}_{2} \mathrm{O}(12,377.3 \mathrm{Da}) ; \mathrm{C}-$ cyt $c-\left(\mathrm{H}_{2} \mathrm{O}\right)_{2}(12,394.6 \mathrm{Da}) ; \mathrm{D}$ - cyt $c-\mathrm{Pt}\left(\mathrm{NH}_{3}\right) \quad(12,569.0 \mathrm{Da}) ; \mathrm{E}-\mathrm{cyt} c-\mathrm{Pt}\left(\mathrm{NH}_{3}\right)_{2}(12,586.2 \mathrm{Da}) ; \mathrm{F}-\mathrm{cyt}$ $c-\mathrm{Pt}\left(\mathrm{NH}_{3}\right)_{2}\left(\mathrm{H}_{2} \mathrm{O}\right)(12,604.3 \mathrm{Da}) ; \mathrm{G}-\mathrm{cyt} c-\mathrm{Na}-\mathrm{Pt}\left(\mathrm{NH}_{3}\right)_{2}\left(\mathrm{H}_{2} \mathrm{O}\right)(12,626.7$ $\mathrm{Da}) ; \mathrm{H}-$ cyt $c-\mathrm{H}_{2} \mathrm{O}-\mathrm{Na}-\mathrm{Pt}\left(\mathrm{NH}_{3}\right)_{2}\left(\mathrm{H}_{2} \mathrm{O}\right)(12,644.3 \mathrm{Da})$.

3 , located within $500-1200 \mathrm{~m} / \mathrm{z}$, give rise to the most abundant signals in the FT-MS spectrum of the free cytochrome $c$ digest.

Under the same conditions, the adduct solution prepared from 1:16 cytochrome $c$ :cisplatin mixture was digested. A detailed comparison of the FT-MS spectra of the adduct digest and the free cytochrome $c$ digest was carried out to identify the new digest fragments in the adduct digest. The FT-MS spectrum of the adduct digest is displayed in Figure 3 (The FT-MS spectrum of the free cytochrome $c$ digest is provided as a Supplementary Figure in the electronic version of this article). In Figure 3, the new fragments in the mass range over $1000 \mathrm{~m} / \mathrm{z}$ with high charges $(+4$ to +6$)$ suggest partial digestion of the adducts. Such partial digestion of the adducts suggests that cisplatin binding to cytochrome $c$ decreases the ability of trypsin to access the cleavable sites. Although extension of the digestion time permits complete digestion, it also leads to an increase in background arising from nonspecific cleavage. Therefore, the digestion time of the cytochrome $c$ adducts was $70 \mathrm{~min}$, the same as the digestion time of free cytochrome $c$.

Further MS ${ }^{n}$ analyses of the new fragments observed in the adduct digest indicate that these fragments correspond to four multiply charged fragments listed in Table 1, obtained by trypsin cleavage at two peptide bonds in the adducts. Of the four fragments, two are $\mathrm{Pt}\left(\mathrm{NH}_{3}\right)_{2}\left(\mathrm{H}_{2} \mathrm{O}\right)$-containing peptides and the other two are heme-containing peptides. The product-ion spectra of these four fragments reveal the primary binding site of cisplatin.

\section{Determination of the Primary Binding Site from Fragment No. 1 and Fragment No. 2}

MS/MS and MS ${ }^{3}$ analyses indicate both $1507.777^{4+}$ and $1206.423^{5+}$ ions arise from fragment no. 1. Figure 4 shows the product-ion spectrum from MS/MS of the $1507.777^{4+}$ ion, in which two abundant doubly charged fragment ions 1456.27 and 1558.18 appear. The total mass of the $1456.27^{2+}$ and $1558.18^{2+}$ ions is $6024.90 \mathrm{Da}$, which has -2.21 Da mass difference from the mass of the parent ion $1507.777^{4+}(6027.11 \mathrm{Da})$, suggesting that $1507.777^{4+}$ primarily fragments at one position during CID to produce the $1456.27^{2+}$ and $1558.18^{2+}$ fragment ions. $\mathrm{MS}^{3}$ analyses of both fragment ions provide additional structural information. $\mathrm{MS}^{3}$ analysis of the $1456.27^{2+}$ ion from the $1507.777^{4+}$ ion, Figure 5, indi-

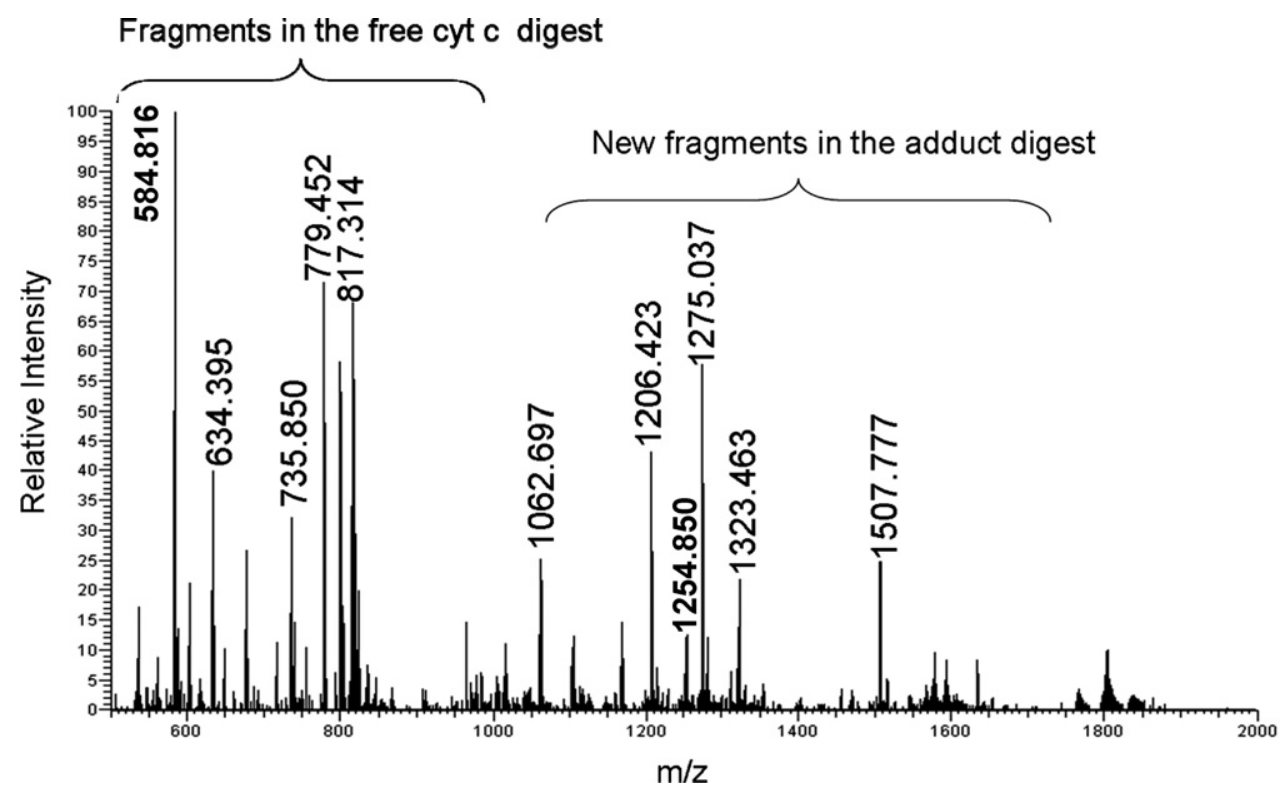

Figure 3. The FT-MS spectrum of the adduct digest. 
Table 1. Four new fragments in the FT-MS spectrum of the adduct digest identified by MS/MS and MS ${ }^{3}$ analyses

\begin{tabular}{lllrr}
\hline \multirow{2}{*}{ Fragments } & \multicolumn{1}{c}{ The fragments' composition } & $m / z$ of the fragments & $\begin{array}{r}\text { Calculated } \\
\text { mass (Da) }\end{array}$ & Measured mass (Da) \\
\hline \hline No. 1 & Gly56-Glu104+ $\mathrm{H}_{2} \mathrm{O}+\mathrm{Pt}\left(\mathrm{NH}_{3}\right)_{2}\left(\mathrm{H}_{2} \mathrm{O}\right)$ & $1507.777^{4+} 1206.423^{5+}$ & 6023.109 & $6027.112 \Delta \mathrm{m}^{*}=4.003$ \\
No. 2 & Asn54-Glu104+ $\mathrm{H}_{2} \mathrm{O}+\mathrm{Pt}\left(\mathrm{NH}_{3}\right)_{2}\left(\mathrm{H}_{2} \mathrm{O}\right)$ & $1568.311^{4+} 1254.850^{5+}$ & 6265.247 & $6269.247 \Delta \mathrm{m}=4.000$ \\
No. 3 & Acety1-Gly1-Lys53+Heme & $1593.546^{4+} 1275.037^{5+} 1062.697^{6+}$ & 6369.124 & $6370.184 \Delta \mathrm{m}=1.060$ \\
No. 4 & Acetyl-Gly1-Lys55+Heme & $1654.077^{4+} 1323.463^{5+} 1102.887^{6+}$ & 6611.262 & $6611.982 \Delta \mathrm{m}=0.720$ \\
\hline
\end{tabular}

${ }^{*} \Delta \mathrm{m}$ is mass deviation of measured mass from calculated mass.

cates that the $1456.27^{2+}$ ion corresponds to a peptide with the sequence Met80-Glu104 (theoretical mass 2909.60 Da). The $1456.27^{2+}$ ion has a mass deviation of $0.93 \mathrm{Da}$ from the theoretical mass of Met80-Glu104. Met80-Glu104 is at the C terminus of the cytochrome $c$ sequence, suggesting that the $1456.27^{2+}$ and $1558.18^{2+}$ ions arise from the cleavage of the Lys79 Met80 peptide bond.

The broader isotope distribution of the ion envelope at $1558.18^{2+}$ compared with that at $1456.27^{2+}$ in Figure 4 suggests $1558.18^{2+}$ corresponds to a $\mathrm{Pt}$-compound containing fragment. Because $\operatorname{Pt}\left(\mathrm{NH}_{3}\right)_{2}\left(\mathrm{H}_{2} \mathrm{O}\right)$ is the primary $\mathrm{Pt}$ compound bound to cytochrome $c$, the peptide mass of $1558.18^{2+}$ is estimated by subtracting the mass of $\mathrm{Pt}\left(\mathrm{NH}_{3}\right)_{2}\left(\mathrm{H}_{2} \mathrm{O}\right)(246.03 \mathrm{Da})$ from the mass of $1558.18^{2+}(2868.33 \mathrm{Da})$. The estimated mass is very close to the mass of the peptide Gly56-Lys79 (theoretical mass $2867.48 \mathrm{Da}$ ) with a mass difference of $0.85 \mathrm{Da}$. The peptide sequence of $1558.18^{2+}$ as Gly56-Lys79 is consistent with the above result that $1558.18^{2+}$ is produced by cleaving the peptide bond Lys79 Met80 in fragment no. 1. Some sequence ions of peptide Lys56-Met79 are also observed in the $\mathrm{MS}^{3}$ analysis of $1507.777^{4+}$ at $1558.18^{2+}$, Figure 6. Consequently, the fragmentation of fragment no. 1 produces two peptide fragments, the $\mathrm{Pt}\left(\mathrm{NH}_{3}\right)_{2}\left(\mathrm{H}_{2} \mathrm{O}\right)$ bound peptide Gly56-Lys79 and the peptide Met80-Glu104. The formation of two peptide fragments in gas-phase from fragment no. 1 suggests that one water molecule is associated with the peptide bond Lys79 Met80. The peptide bond Lys79 Met80 is not cleaved in trypsin digestion even after it is associated with one water molecule, suggesting the interactions $\mathrm{Pt}\left(\mathrm{NH}_{3}\right)_{2}\left(\mathrm{H}_{2} \mathrm{O}\right)$ with the peptide Gly56-Glu104 results in a more stable Lys79 Met80 peptide bond.

In Figure 6, $1531.64^{2+}$ is the primary product ion produced by neutral loss of two $\mathrm{H}_{2} \mathrm{O}$ and one $\mathrm{NH}_{3}$ from the $1558.18^{2+}$ ion, indicating the peptide bonds in the $1558.18^{2+}$ ion are hard to break due to the $\mathrm{Pt}\left(\mathrm{NH}_{3}\right)_{2}\left(\mathrm{H}_{2} \mathrm{O}\right)$ binding. Most peaks are enlarged 20 times in Figure 6 to display the sequence ions for the peptide Gly56-Lys79 and the Pt-compound containing fragment ions $\left(1383.45^{+}, 1419.36^{+}\right.$, and $\left.1952.82^{+}\right)$. The strong intensity of $\mathrm{y}_{14}{ }^{+}\left(1679.82^{+}\right)$suggests that the peptide bond Met65 Glu66 readily fragments. The calculated mass of the complementary ion of $\mathrm{y}_{14}{ }^{+}$is 1436.54 Da, which is close to the molecular mass of $\left[b_{10}+\operatorname{Pt}\left(\mathrm{NH}_{3}\right)_{2}\left(\mathrm{H}_{2} \mathrm{O}\right)\right]^{+}$(theoretical mass1435.62 Da). However, the $1383.45^{+}$and $1419.36^{+}$ions are observed and assigned as the Pt-compound containing $\mathrm{b}_{10}{ }^{+}$ions because neutral loss dominates during fragmenting the $1558.18^{2+}$ ion, indicated by the primary fragment ion $1531.64^{2+}$ in Figure 6. Based on the assignments of the $\mathrm{Pt}$-compound containing fragment ions, the Pt compounds bind to one of the amino acid residues of the $\mathrm{b}_{10}{ }^{+}$ion (Gly56-Met65), in which Met65 has highest affinity for the $\mathrm{Pt}(\mathrm{II})$ compounds. Therefore, Met65 is the most probable binding site for $\mathrm{Pt}\left(\mathrm{NH}_{3}\right)_{2}\left(\mathrm{H}_{2} \mathrm{O}\right)$. Met65 is located in the middle of the fragment Gly56-

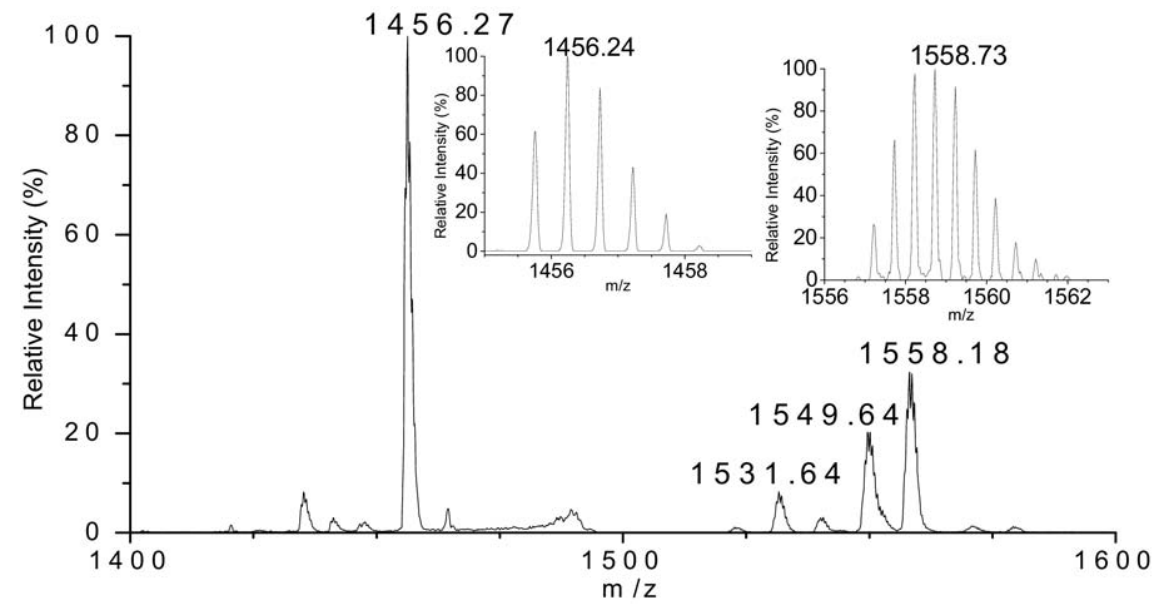

Figure 4. The product-ion spectrum of the MS/MS analysis of $1507.777^{4+}$ and zoom scans of the product ions $1456.27^{2+}$, and $1558.18^{2+}$. 
Lys79 and the tight interaction between $\mathrm{Pt}\left(\mathrm{NH}_{3}\right)_{2}\left(\mathrm{H}_{2} \mathrm{O}\right)$ and Met65, contributes to strong peptide bonds in the $\mathrm{MS}^{3}$ analysis of $1507.777^{4+}$ at $1558.18^{2+}$.

The MS/MS and $\mathrm{MS}^{3}$ analyses of fragment no. 2 indicate that fragment no. 2 is the $\mathrm{Pt}\left(\mathrm{NH}_{3}\right)_{2}\left(\mathrm{H}_{2} \mathrm{O}\right)$ bound Asn54-Glu104 and Met65 is the $\operatorname{Pt}\left(\mathrm{NH}_{3}\right)_{2}\left(\mathrm{H}_{2} \mathrm{O}\right)$ binding site on the peptide Asn54-Glu104 (data not shown).

\section{Identification of Fragment No. 3 and Fragment No. 4}

Fragment no. 3 is represented by three ions $1593.546^{4+}$, $1275.037^{5+}, 1062.697^{6+}$, and fragment no. 4 is also observed as three ions $1654.077^{4+}, 1323.463^{5+}, 1102.887^{6+}$, in Figure 3. A $617.27 \mathrm{~m} / \mathrm{z}$ ion is observed in the product spectra of the MS/MS analyses of fragment no. 3 and fragment no. 4, indicating both fragments contain the heme group. Comparison of the product spectra of the MS/MS analyses of the most abundant ions, $1275.037^{5+}$ for fragment no. 3 and $1323.463^{5+}$ for fragment no. 4 (spectra not shown), reveals similar fragmentation patterns and several common fragment ions, suggesting that fragment no. 3 and fragment no. 4 are of similar structure. Further spectral analysis indicates that fragment no. 3 is identified as a heme containing peptide, the sequence of which is Acetyl-Gly1-Lys53, produced by cleaving Lys53 Asn54 in trypsin digestion. Fragment no. 4 is a heme bound peptide, acetyl-Gly1-Lys55, produced by cleaving Lys55 Gly56 in trypsin digestion. Therefore, fragment no. 3 is complementary to fragment no. 2 and fragment no. 4 is complementary to fragment no. 1 according to the cytochrome $c$ sequence, suggesting the cleavage mainly occurred at two positions (Lys53 Asn54 and Lys55 Gly56) in trypsin digestion of the cytochrome $c$ adduct. The results of the $\mathrm{MS}^{n}$ analyses of the four fragments indicate that Met65 is the primary binding site of cisplatin on cytochrome $c$,

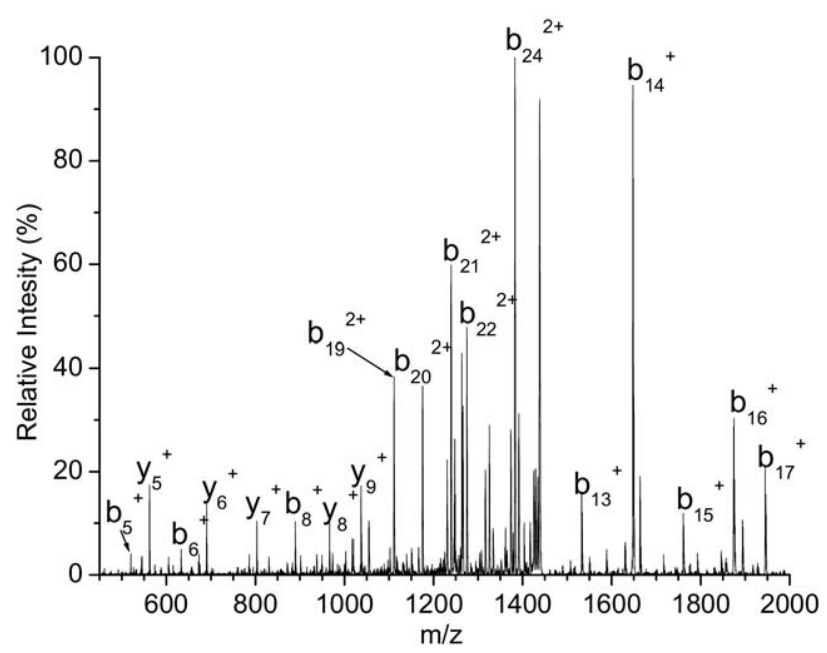

Figure 5. The product-ion spectrum of the $\mathrm{MS}^{3}$ analysis of $1507.777^{4+}$ at $1456.27^{2+}$ : the peptide sequence of $1456.27^{2+}$ : (Met80-Glu104) MIFAGIKKKTEREDLIAYLKKATNE.

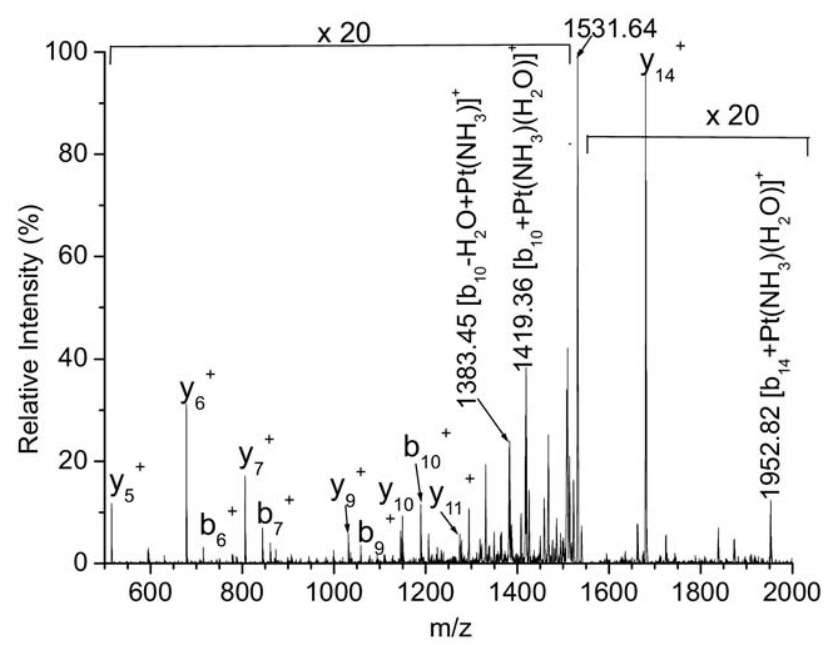

Figure 6. The product-ion spectrum of the $\mathrm{MS}^{3}$ analysis of $1507.777^{4+}$ at $1558.18^{2+}$ : the peptide sequence of $1558.18^{2+}$ : (Gly56-Lys79) GITWKEETLMEYLENPKKYI PGTK.

which is consistent with the previously reported results from NMR [9].

\section{Conclusions}

This research illustrates a mass spectrometric method for the direct determination of the primary binding site of cisplatin on cytochrome $c$. ESI-MS data reveal that the cytochrome $c-t\left(\mathrm{NH}_{3}\right)_{2}\left(\mathrm{H}_{2} \mathrm{O}\right)$ monoadduct is the primary adduct produced by the cytochrome $c$-cisplatin interactions under native conditions in $30 \mathrm{~h}$. Four new fragments appear in the adduct digest compared with the free cytochrome $c$ digest. The complete identification of these four fragments suggests that the cytochrome $c$ adducts are cleaved mainly at two positions Lys53 Asn 54 and Lys55 Gly56 by trypsin. These data support the assignment of Met65 as the primary binding site of cisplatin on cytochrome $c$. Therefore, the monoadduct cytochrome $c-\mathrm{Pt}\left(\mathrm{NH}_{3}\right)_{2}\left(\mathrm{H}_{2} \mathrm{O}\right)$ arises from covalent interactions between $\mathrm{Pt}\left(\mathrm{NH}_{3}\right)_{2}\left(\mathrm{H}_{2} \mathrm{O}\right)$ and Met65 in cytochrome $c$. The high specificity of this MS method enables direct determination of the primary cisplatin binding site without need for additional sample purification. The successful identification implies that this mass spectrometric approach based on FT-MS and $\mathrm{MS}^{n}$ can be useful in the exploration of the binding site(s) of the $\mathrm{Pt}$ metallodrugs on other proteins.

\section{Acknowledgments}

The authors gratefully acknowledge funding from the NSF EPSCoR program that provided the LTQ-FT mass spectrometer employed in these studies. The authors appreciate Dr. Zhongqi Zhang for kindly providing the MagTran software used in the ESI-MS spectral deconvolution. They thank Brent Robert Reschke for help in conducting the FTMS experiments and Megan DeJesus for valuable editorial suggestions on the manuscript. 


\section{Appendix Supplementary Material}

Supplementary material associated with this article may be found in the online version at doi:10.1016/ j.jasms.2009.02.013.

\section{References}

1. Jamieson, E. R.; Lippard, S. J. Structure, recognition, and processing of cisplatin-DNA adducts. Chem. Rev. 1999, 99, 2467-2498.

2. Lippert, B. Cisplatin: Chemistry and Biochemistry of a Leading Anticancer Drug; Wiley-VCH, New York, 1999.

3. Hickman, J. A. Apoptosis induced by anticancer drugs. Cancer Metast. Rev. 1992, 11, 121-139.

4. Hurley, L. H.; Boyd, F L. DNA as a target for drug action. Trends Pharmacol. Sci. 1988, 9, 402-407.

5. DeConti, R. C.; Toftness, B. R.; Lange, R. C.; Creasey, W. A. Clinical and pharmacological studies with cis-diamminedichloroplatinum (II). Cancer Res. 1973, 33, 1310-1315.

6. Timerbaev, A. R.; Hartinger, C. G.; Aleksenko, S. S.; Keppler, B. K. Interactions of antitumor metallodrugs with serum proteins: Advances in characterization using modern analytical methodology. Chem. Rev. 2006, 106, 2224-2248.

7. Appleton, T. G. Donor atom preferences in complexes of platinum and palladium with amino acids and related molecules. Coord. Chem. Rev. 1997, 166, 313-359.

8. Ivanov, A. I.; Christodoulou, J.; Parkinson, J. A.; Barnham, K. J.; Tucker, A.; Woodrow, J.; Sadler, P. J. Cisplatin binding sites on human albumin. J. Biol. Chem. 1998, 273, 14721-14730.

9. Jiang, L.; Chen, Y.; Tang, G.; Tang, W. Studies on the interaction between cytochrome $c$ and cis- $\mathrm{PtCl}_{2}\left(\mathrm{NH}_{3}\right)_{2}$. J. Inorg. Biochem. 1997, 65, 73-77.

10. Calderone, V.; Casini, A.; Mangani, S.; Messori, L.; Orioli, P. L. Structural investigation of cisplatin-protein interactions: Selective platination of His19 in a cuprozinc superoxide dismutase. Angew. Chem. Int. Ed. 2006, 45, 1267-1269.

11. Casini, A.; Mastrobuoni, G.; Temperini, C.; Gabbiani, C.; Francese, S.; Moneti, G.; Supuran, C. T.; Scozzafava, A.; Messori, L. ESI mass spectrometry and X-ray diffraction studies of adducts between anticancer platinum drugs and hen egg white lysozyme. Chem. Commun. 2007, 2, 156-158.

12. Heck, A. J. R.; Van Den Heuvel, R. H. H. Investigation of intact protein complexes by mass spectrometry. Mass Spectrom. Rev. 2004, 23, 368-389.

13. Loo, J. A. Studying noncovalent protein complexes by electrospray ionization mass spectrometry. Mass Spectrom. Rev. 1997, 16, 1-23.

14. Carr, S. A.; Annan, R. S.; Huddleston, M. J. Mapping post-translational modifications of proteins by MS-based selective detection: application to phosphoproteomics. Methods Enzymol. 2005, 405, 82-115.
15. Gibson, D.; Costello, C. E. A mass spectral study of the binding of the anticancer drug cisplatin to ubiquitin. Eur. Mass Spectrom. 1999, 5 501-510.

16. Peleg-Shulman, T.; Gibson, D. Cisplatin-protein adducts are efficiently removed by glutathione but not by 5 '-guanosine monophosphate. JACS 2001, 123, 3171-3172.

17. Allardyce, C. S.; Dyson, P. J.; Coffey, J.; Johnson, N. Determination of drug binding sites to proteins by electrospray ionization mass spectrometry: The interaction of cisplatin with transferrin. Rapid Commun Mass Spectrom. 2002, 16, 933-935.

18. Khalaila, I.; Allardyce, C. S.; Verma, C. S.; Dyson, P. J. A mass spectrometric and molecular modelling study of cisplatin binding to transferrin. Chembiochemistry 2005, 6, 1788-1795.

19. Hartinger, C. G.; Ang, W. H.; Casini, A.; Messori, L.; Keppler, B. K.; Dyson, P. J. Mass spectrometric analysis of ubiquitin-platinum interactions of leading anticancer drugs: MALDI versus ESI. J. Anal. At. Spectrom. 2007, 22, 960-967.

20. Hartinger, C. G.; Tsybin, Y. O.; Fuchser, J.; Dyson, P. J. Characterization of platinum anticancer drug protein-binding sites using a top-down mass spectrometric approach. Inorg. Chem. 2008, 47, 17-19.

21. Bushnell, G.; Louie, G.; Brayer, G. High-resolution three-dimensional structure of horse heart cytochrome c. Mol. Biol. 1990, 214, 585-595.

22. Yang, G.; Miao, R.; Jin, C.; Mei, Y.; Tang, H.; Hong, J.; Guo, Z.; Zhu, L. Determination of binding sites in carboplatin-bound cytochrome c using electrospray ionization mass spectrometry and tandem mass spectrometry. J. Mass. Spectrom. 2005, 40, 1005-1016.

23. Casini, A.; Gabbiani, C.; Mastrobuoni, G.; Messori, L.; Moneti, G. Pieraccini, G. Exploring metallodrug-protein interactions by ESI mass spectrometry: The reaction of anticancer platinum drugs with horse heart cytochrome c. Chem. Med. Chem. 2006, 1, 413-417.

24. Casini, A.; Gabbiani, C.; Mastrobuoni, G.; Pellicani, R. Z.; Intini, F. P.; Arnesano, F.; Natile, G.; Moneti, G.; Francese, S.; Messori, L. Insights into the molecular mechanisms of protein platination from a case study: The reaction of anticancer platinum(II) iminoethers with horse heart cytochrome c. Biochemistry 2007, 46, 12220-12230.

25. Marshall, A. G.; Hendrickson, C. L.; Jackson, G. S. Fourier transform ion cyclotron resonance mass spectrometry: A primer. Mass Spectrom. Rev. $1998,17,1-35$

26. Medzihradszky, K. F. Peptide sequence analysis. Methods Enzymol. 2005, 402, 209-244.

27. Tang, L.; Kebarle, P. Dependence of ion intensity in electrospray mass spectrometry on the concentration of the analytes in the electrosprayed solution. Anal. Chem. 1993, 65, 3654-3668.

28. Gabelica, V.; Galic, N.; Rosu, F.; Houssier, C.; Pauw, E. D. Influence of response factors on determining equilibrium association constants of noncovalent complexes by electrospray ionization mass spectrometry. $J$. Mass Spectrom. 2003, 38, 491-501.

29. Zhang, Z.; Marshall, A. G. A universal algorithm for fast and automated charge state deconvolution of electrospray mass-to-charge ratio spectra. J. Am. Soc. Mass Spectrom. 1998, 9, 225-233.

30. Qi, P. X.; Urbauer, J. L.; Fuentes, E. J.; Leopold, M. F.; Wand, A. J. Structural water in oxidized and reduced horse heart cytochrome $c$. Nature Struct. Biol. 1994, 1, 378-382.

31. Medzihradszky, K. F. In-solution digestion of proteins for mass spectrometry. Methods Enzymol. 2005, 405, 50-65. 